\title{
PENGARUH ZAKAT TERHADAP PERTUMBUHAN EKONOMI INDONESIA TAHUN 2007-2018
}

\author{
Roisyatin, Jamaludin \\ Institut Ummul Quro Al-Islami Bogor-Indonesia \\ roisiyatin@iuqibogor.ac.id
}

Naskah masuk:02-01-2020, direvisi:04-02-2020, diterima:01-03-2020, dipublikasi:18-03-2020

\begin{abstract}
ABSTRAK
Penelitian ini memiliki dua pertanyaan inti yang dijawab dalam sebuah analisis deskriptif. Pertama, apakah penyaluran dana zakat berpengaruh terhadap pendapatan nasional Indonesia. Kedua, apakah penyaluran dana zakat kepada masyarakat mustahiq di Indonesia berpengaruh terhadap pertumbuhan ekonomi. Metode dalam penelitian ini menggunakan metode deskriptif kuantitatif yang mendeskripsikan fenomena-fenomena berdasarkan fakta data yang diambil dari data sekunder yang dirilis dari sasaran penelitian. Teknik penelitian yang dilakukan adalah dengan melakukan observasi mengumpulkan sumber data penelitian berupa data sekunder nominal dana penyaluran zakat dari rilis yang dipublikasikan melalui website resmi BAZNAS dan pertumbuhan ekonomi Inonesia dengan indikator PDB dari rilis yang dipublikasikan melalui website resmi BPS. Hasil analisis dikemukakan nilai konstanta 171,926 dan mempunyai koefisien regresi sebesar 0,591 menunjukkan bila faktor dana zakat bernilai 0 (konstan), maka PDB sebesar $=0,591$. Ini menunjukkan angka positif yang artinya bahwa setiap peningkatan penerimaan dana zakat sebesar $1 \%$, maka akan terjadi perubahan PDB sebesar $=0,591$. Hal ini disebabkan karena zakat yang diberikan berpengaruh terhadap pendapatan masyarakat yang menerimanya sehingga dapat meningkatkan pendapatan skala nasional (PDB) yang pada akhirnya dapat meningkatkan pertumbuhan ekonomi Indonesia. Diketahui juga bahwa koefisien korelasi (R) = 0,591 atau 59,1\% yang menunjukan bahwa derajat hubungan (korelasi) antara variabel bebas (dana zakat) dengan variabel terikat pertumbuhan ekonomi (PDB) memiliki hubungan (korelasi). Koefisien determinasi $\left(\mathrm{R}^{2}\right)$ diketahui sebesar $=0,329$ atau 32,9\%, artinya variabel terikat (PDB) dapat dipengaruhi sebesar $32,9 \%$ oleh dana zakat, dan sisanya sebesar $67,1 \%$ dipengaruhi oleh faktor lain yang tidak termasuk dalam penelitian ini. Dari hasil nilai determinasi $\left(\mathrm{R}^{2}\right)$ pengaruh dana zakat terhadap PDB relatif lemah, ini terjadi karena PDB harga konstan (riil) yang dianalisis dalam penelitian ini menunjukkan laju pertumbuhan ekonomi secara keseluruhan atau setiap sektor dari tahun ke tahun, namun angka yang digunakan pada penelitian ini dibatasi pada sektor pengeluaran konsumsi rumah tangga. Maka kesimpulan dari penelitian ini menunjukkan bahwa dana zakat $(\mathrm{X})$ berpengaruh positif terhadap pertumbuhan ekonomi indikator PDB di Indonesia periode 2007-2018. Zakat sebagai salah satu syariat yang ditetapkan Allah SWT untuk kemaslahatan umat manusia berperan penting pada cetak biru pembangunan ekonomi Indonesia.

Kata Kunci: PDB, Pertumbuhan Ekonomi, Zakat
\end{abstract}

\section{ABSTRACT}

This study has two core questions which are answered in a descriptive analysis. First, does the distribution of zakat funds has an affect to Indonesia's national income?. The second, whether the distribution of zakat funds to Mustahiq in Indonesia has an effect to economic growth? The results of the analysis revealed a constant value of 171.926 and has a regression coefficient of 0.591 indicating if the zakat fund factor is 0 (constant), then GDP is $=0.591$. This shows a positive number which means 
that every $1 \%$ increase in the receipt of zakat funds, there will be a change in GDP of $=0.591$. This is because zakat given affects the income of the people who receive it, so that it can increase national scale income (GDP) which in turn can increase Indonesia's economic growth. It is also known that the correlation coefficient $(R)=0.591$ or $59.1 \%$ which shows that the degree of relationship (correlation) between the independent variable (zakat fund) with the dependent variable of economic growth (GDP) has a relationship (correlation). The coefficient of determination (R2) is known as $=0.329$ or $32.9 \%$, meaning that the dependent variable (GDP) can be influenced by $32.9 \%$ by zakat funds, and the remaining $67.1 \%$ is influenced by other factors not included in this study. From the results of the determination value (R2) the effect of zakat funds on GDP is relatively weak, this is because the constant (real) GDP prices analyzed in this study indicate the overall economic growth rate or each sector from year to year, but the figures used in this study limited to household consumption expenditure sectors. So the conclusion of this study shows that the zakat fund $(X)$ has a positive effect on the economic growth of GDP indicators in Indonesia for the period 2007-2018. Zakat as one of the sharia set by Allah SWT for the benefit of humanity plays an important role in the blueprint for Indonesia's economic development. Keywords: GDP, Economic Growth, Zakat

\section{PENDAHULUAN}

Permasalahan ekonomi akan terus terjadi dari masa ke masa, karena ekonomi merupakan salah satu faktor terpenting terhadap kemajuan suatu pemerintahan (Qardhawi:2005), maka konsep kesejahteraan terus dikembangkan. Di samping itu juga, kesejahteraan masyarakat juga menjadi penentu pertumbuhan ekonomi suatu negara.

Dalam perspektif ekonomi Islam terdapat faktor yang mempengaruhi kesejahteraan dan pertumbuhan ekonomi yaitu penyaluran dana filantropi berupa zakat, infak dan sedekah (ZIS). Penyaluran dana ZIS ini sebagai pendorong pertumbuhan ekonomi, menurut Riyandono (2008: 54) dalam Islam diwajibkan untuk mengeluarkan zakat, yang memiliki fungsi untuk memaksa seseorang menjadikan hartanya agar senantiasa produktif atau senantiasa berputar. Dengan harta yang selalu produktif ini maka akan meningkatkan output (perkembangan dan pertumbuhan ekonomi), penyerapan tenaga kerja, peningkatan pendapatan, kesejahteraan masyarakat dan lain sebagainya. Dapat dilihat pada Tabel 1.1. berikut:

Tabel 1 Penyaluran ZIS pada BAZNAS periode 2011-2015

\begin{tabular}{|c|c|c|}
\hline Tahun & Penyaluran dana ZIS & $(\%)$ \\
\hline 2011 & $39.804 .731 .212,00$ & $19,4 \%$ \\
\hline 2012 & $38.513 .551 .378,00$ & $18,8 \%$ \\
\hline 2013 & $44.363 .070 .093,00$ & $21,6 \%$ \\
\hline 2014 & $55.990 .121 .023,00$ & $27,2 \%$ \\
\hline 2015 & $26.500 .542 .731,00$ & $12,9 \%$ \\
\hline
\end{tabular}

Sumber: Badan Amil Zakat Nasional (BAZNAS), www.baznas.go.id

Dengan semakin meningkatnya penyaluran dana ZIS maka hal tersebut dapat mendorong pertumbuhan ekonomi di Indonesia. Nilai strategis zakat dapat dilihat melalui: Pertama, zakat merupakan panggilan agama, Ia merupakan cerminan dari keimanan seseorang. Kedua, sumber keuangan zakat tidak akan pernah berhenti. Artinya orang yang membayar zakat tidak akan pernah habis dan yang telah membayar setiap tahun atau periode waktu yang lain akan terus membayar. Ketiga, zakat secara empirik dapat menghapus kesenjangan sosial dan sebaliknya dapat menciptakan redistribusi aset dan 
pemerataan pembangunan. Pemberdayaan zakat, infaq dan shodaqah merupakan strategi untuk meningkatkan kesejahteraan hidup masyarakat serta upaya mengurangi ketergantungan ekonomi Indonesia terhadap bantuan-bantuan luar, dan membebaskan masyarakat dari problem kemiskinan.

Menurut survey yang dilakukan Badan Amil Zakat Nasional (Baznas) bersama Institut Pertanian Bogor (IPB) dan IRTI-IDB pada 2011 menemukan bahwa potensi zakat nasional mencapai Rp 217,3 triliun dari total pendduduk muslim di Indonesia. Maka, data-data tersebut memberikan gambaran bahwa zakat jika dikelola dengan baik bisa menjadi sumber kekuatan dalam memberdayakan kondisi perekonomian negara dan masyarakat. Bertitik tolak dari penjelasan tersebut, maka dilakukanlah sebuah penelitian berupa "Pengaruh zakat Terhadap Pertumbuhan Ekonomi Indonesia Tahun 2007-2018".

\section{METODE PENELITIAN}

Metode dalam penelitian ini menggunakan metode deskriptif kuantitatif yang mendeskripsikan fenomena-fenomena berdasarkan fakta data yang diambil dari data sekunder yang dirilis dari sasaran penelitian. Karena penelitian ini adalah jenis penelitian deskriptif kuantitatif, maka data yang diambil berasal dari data sekunder yang dirilis dari sasaran penelitian, maka teknik penelitian yang dilakukan adalah dengan melakukan observasi mengumpulkan sumber data penelitian berupa data sekunder nominal dana penyaluran zakat dari rilis yang dipublikasikan melalui website resmi BAZNAS dan pertumbuhan ekonomi Inonesia dengan indikator PDB dari rilis yang dipublikasikan melalui website resmi BPS. Data kuantitatif yang diperoleh dari website BAZNAS dan BPS diolah dengan menggunakan analisis regresi linier yang digunakan untuk menganalisis adanya pengaruh antara dana penyaluran zakat terhadap pertumbuhan ekonomi di Indonesia dalam kurun waktu sepuluh tahun (2007-2018).

\section{HASIL DAN PEMBAHASAN}

Karena objek penelitian ini adalah data nominal dana zakat yang didistribusikan secara nasional yang diambil dari BAZNAS (Badan Amil Zakat Nasional) dan data GDP (Gross Domestic Product) atau PDB (Produk Domestik Bruto) Indonesia yang menunjukkan pertumbuhan ekonomi, maka data tidak langsung diperoleh dari lapangan penelitian.

Data yang dianalisis dalam penelitian ini adalah dana zakat yang berhasil dihimpun dan didistribusikan oleh BAZNAS dan data PDB dalam miliar rupiah.

Tabel 2 Dana Zakat dan PDB di Indonesia Tahun 2007-2018

(Dalam Milyar Rupiah)

\begin{tabular}{|c|c|c|c|}
\hline No & Bulan, Tahun & Dana Zakat (X)* & $\begin{array}{c}\text { Pertumbuhan } \\
\text { Ekonomi Indikator } \\
\text { PDB (Y)* }\end{array}$ \\
\hline 1 & 2007 & 8307940585 & 58360000000 \\
\hline 2 & 2008 & 15355092415 & 11911908000 \\
\hline 3 & 2009 & 19371179661 & 57330000000 \\
\hline 4 & 2010 & 23661022281 & 378606290000 \\
\hline 5 & 2011 & 32986949797 & 426007554000 \\
\hline 6 & 2012 & 40387972149 & 476874507000 \\
\hline 7 & 2013 & 50741735215 & 532108763000 \\
\hline
\end{tabular}




\begin{tabular}{|c|c|c|c|}
\hline No & Bulan, Tahun & Dana Zakat $(\mathrm{X})^{*}$ & $\begin{array}{c}\text { Pertumbuhan } \\
\text { Ekonomi Indikator } \\
\text { PDB (Y)* } \\
\end{array}$ \\
\hline 8 & 2014 & 69865506671 & 463183000000 \\
\hline 9 & 2015 & 82272643293 & 649092968000 \\
\hline 10 & 2016 & 97637657910 & 702702346000 \\
\hline 11 & Jan-17 & 7838554257 & 183771690000 \\
\hline 12 & Feb-17 & 5219054473 & 183771690000 \\
\hline 13 & Mar-17 & 11843948658 & 183771690000 \\
\hline 14 & Apr-17 & 6666795733 & 187375878000 \\
\hline 15 & Mei-17 & 11843486420 & 187375878000 \\
\hline 16 & Jun-17 & 36386504708 & 187375878000 \\
\hline 17 & Jul-17 & 11302882813 & 195266881000 \\
\hline 18 & Agu-17 & 9303862772 & 195266881000 \\
\hline 19 & Sep-17 & 7123238610 & 195266881000 \\
\hline 20 & Okt-17 & 8037663751 & 196342946000 \\
\hline 21 & Nov-17 & 8692507067 & 196342946000 \\
\hline 22 & Des-17 & 10625935791 & 762757395000 \\
\hline 23 & Jan-18 & 9142659948 & 199237607000 \\
\hline 24 & Feb-18 & 11912857860 & 199237607000 \\
\hline 25 & Mar-18 & 8548498242 & 199237607000 \\
\hline 26 & Apr-18 & 9998514258 & 203547726000 \\
\hline 27 & Mei-18 & 19187662656 & 203547726000 \\
\hline 28 & Jun-18 & 38084984822 & 203547726000 \\
\hline 29 & Jul-18 & 13413117593 & 211413691000 \\
\hline 30 & Agu-18 & 9263744424 & 211413691000 \\
\hline 31 & Sep-18 & 8654561047 & 211413691000 \\
\hline 32 & Okt-18 & 9960373655 & 212776365000 \\
\hline 33 & Nov-18 & 8692507067 & 212776365000 \\
\hline 34 & Des-18 & 14325654117 & 826975390000 \\
\hline
\end{tabular}

Sumber : *Laporan Keuangan BAZNAS, www.baznas.go.id **Data BPS, www.bps.go.id

Dari data di atas, digunakan perhitungan dengan metode regresi linier sederhana yang dihitung menggunakan program SPSS berupa Descriptive Statistics (Statistika deskriptif) yaitu teknik yang digunakan untuk mensarikan data dan menampilkannya dalam bentuk yang dapat dimengerti oleh setiap orang. Hasil yang diperoleh dapat memberikan pengetahuan yang signifikan pada kejadian fenomena yang belum dikenal dan mendeteksi keterkaitan yang ada di dalamnya.

Variabel operasional dalam penelitian ini adalah sebagai berikut :

A. PDB (Y) sebagai variabel terikat (dependent) : jumlah nominal Produk Domestik Bruto pengeluaran skala nasional atas barang dan jasa oleh rumah tangga untuk tujuan konsumsi (di ukur dengan rupiah).

B. Jumlah dana zakat (X) sebagai variabel bebas (independent) : yaitu jumlah penyaluran dana zakat yang diberikan oleh BAZNAS 
Melalui penelitian ini dianalisis apakah terdapat pengaruh antara PDB (Y) sebagai variabel terikat (dependent) dan jumlah dana zakat (X) sebagai variabel bebas (independent). Setelah dilakukan analisa statistik deskriptif, diperoleh nilai sebagai berikut:

Tabel 3 Descriptive Statistics

\begin{tabular}{|c|c|c|c|c|c|}
\hline & N & Minimum & Maximum & Mean & Std. Deviation \\
\hline $\begin{array}{c}\text { DANA } \\
\text { ZAKAT }\end{array}$ & 34 & 5219054473 & 97637657910 & 21666390315,26 & 22663490140,077 \\
PDB & 34 & 11911908000 & 826975390000 & 285470269470,59 & $\begin{array}{c}200976841837,99 \\
7\end{array}$ \\
$\begin{array}{c}\text { Valid N } \\
\text { (listwise) }\end{array}$ & 34 & & & & \\
\hline
\end{tabular}

Sumber: Data diolah, 2019.

Tabel di atas menyajikan dua variabel yaitu variabel dana zakat $(\mathrm{X})$ dan variabel PDB (Y). Hasil deskriptif variabel dana zakat (X) dalam tabel descriptive statistics dijelaskan bahwa terdapat jumlah data $(\mathrm{N})=34$; rata-rata (mean) sebesar Rp 21.666.390.315,26, artinya dalam kurun waktu 2007-2018 dana zakat yang berhasil disalurkan BAZNAS di Indonesia adalah sebesar Rp 21.666.390.315,26 dan untuk simpangan baku (standar deviasi) = Rp 22.663.490.140,077. Sedangkan variabel PDB dijelaskan dengan jumlah data $(\mathrm{N})=34$ dengan rata-rata (mean) sebesar Rp 285.470.269.470,59, artinya dalam kurun waktu 2007-2018 secara skala nasional PDB Indonesia rata-rata sebesar Rp285.470.269.470,59 dan simpangan baku (standar deviasi) = Rp 200.976.841.837,997.

\section{Uji Normalitas}

Uji Normalitas adalah pengujian yang dilakukan untuk mengetahui apakah distribusi sebuah data mengikuti atau mendekati distribusi normal, yakni distribusi data dengan bentuk lonceng (bell shaped). Data yang baik adalah data yang mempunyai pola seperti distribusi normal, yaitu distribusi data tersebut tidak menceng ke kanan danke kiri. Uji normalitas pada multivariate sebenarnya sangat kompleks karena harus dilakukan pada sebuah variabel secara bersama-sama. Namun, uji ini bisa juga dilakukan pada sebuah variabel dengan logika bahwa jika secara individual tiap-tiap variabel memenuhi asumsi normalitas, maka secara bersama-sama (multivariate) variabel-variabel tersebut dianggap memenuhi asumsi normalitas.

Uji normalitas menggunakan kolmogorov smirnov tes dan normal probability plot sebagai berikut:

Tabel 4 Uji Normalitas Kolmogorov-Smirnov Test

\begin{tabular}{|l|l|r|}
\hline \multicolumn{2}{|c|}{ One-Sample Kolmogorov-Smirnov Test } \\
\hline \multicolumn{2}{|l|}{} & \multicolumn{1}{|c|}{$\begin{array}{c}\text { Unstandardized } \\
\text { Residual }\end{array}$} \\
\hline N & \multicolumn{1}{|c|}{34} \\
\hline Normal Parameters ${ }^{\mathrm{a}, \mathrm{b}}$ & Mean &,- 000036 \\
\cline { 2 - 3 } & Std. Deviation & 162128241815,2079 \\
& & 8000 \\
\hline
\end{tabular}




\begin{tabular}{|l|l|r|}
\hline \multirow{2}{*}{$\begin{array}{l}\text { Most Extreme } \\
\text { Differences }\end{array}$} & Absolute &, 276 \\
\cline { 2 - 3 } & Positive &, 276 \\
\cline { 2 - 3 } & Negative &, 175 \\
\hline Test Statistic &, $000^{c}$ \\
\hline Asymp. Sig. (2-tailed) \\
\hline \multicolumn{2}{|l|}{ a. Test distribution is Normal. } \\
\hline \multicolumn{2}{|l|}{ b. Calculated from data. } \\
\hline \multicolumn{2}{|l}{ c. Lilliefors Significance Correction. } \\
\hline
\end{tabular}

Sumber: Data diolah, 2019

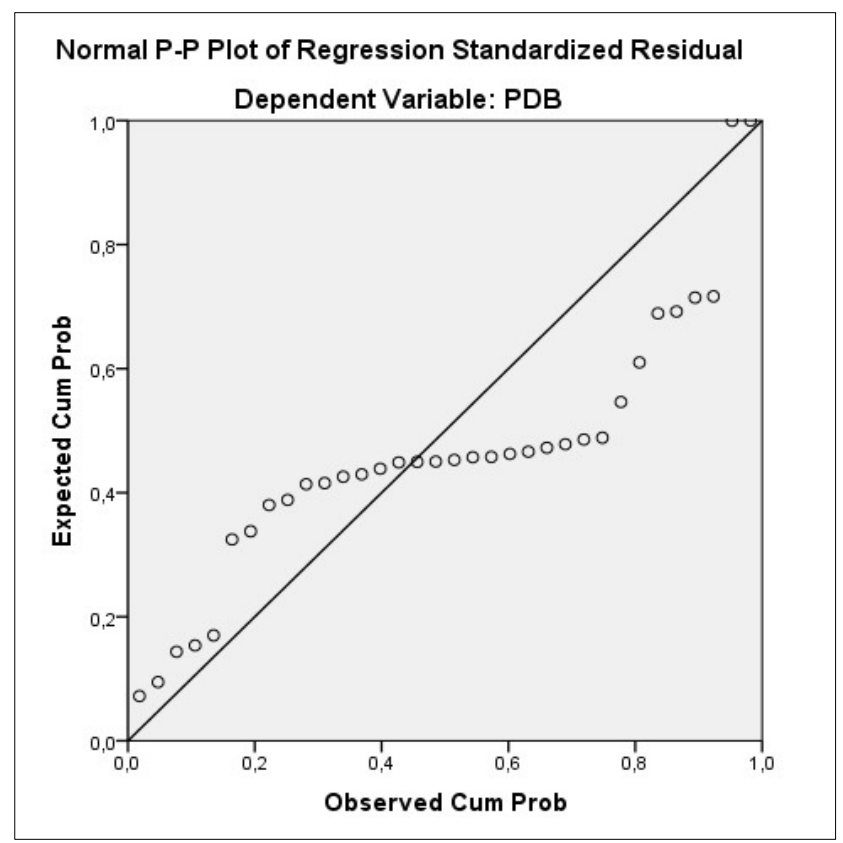

Gambar 1 Uji Normalitas Normal Probability Plot Sumber: Data diolah, 2019

Dari grafik normal probability plot (PP-Plot) of regression standarized residual yang membandingkan distribusi komulatif dari distribusi normal. Distribusi normal akan membentuk satu garis lurus diagonal, dan plooting data akan dibandingkan dengan garis diagonal. jika distribusi data tersebut normal, maka garis yang mengambarkan data sesungguhnya akan mengikuti garis diagonalnya. Jika distribusi data residual normal, maka titik sebaran data tersebar tidak terlalu jauh (mengikuti) arah garis diagonalnya.

\section{Pengujian Hipotesis}

Untuk mengetahui pengaruh variabel bebas secara parsial atau individu terhadap variabel tidak bebas dengan asumsi variabel yang lain konstan. Pengujian ini dilakukan dengan melihat derajat signifikansi masing-masing variabel bebas.

Pengujian hipotesis menggunakan uji t, menggunakan tingkat keyakinan (level of signifikan) atau $\alpha=0,05$ dengan ketentuan :

Apabila $t_{\text {hitung }}<t_{\text {tabel}}$, maka Ho diterima artinya dana zakat tidak berpengaruh terhadap pertumbuhan ekonomi (PDB) Indonesia. 
Apabila $t_{\text {hitung }}>t_{\text {tabel, }}$ maka Ho ditolak artinya dana zakat berpengaruh terhadap pertumbuhan ekonomi (PDB) Indonesia.

A. Jika probabilitas (signifikansi) $>0,05(\alpha)$ maka Ho diterima

B. Jika probabilitas (signifikansi) $<0,05(\alpha)$ maka Ho ditolak dan Hi diterima

Uji t digunakan untuk mengetahui apakah variabel bebas yaitu dana zakat (x) berpengaruh terhadap variabel terikat pertumbuhan ekonomi dengan indikator PDB (y) dengan asumsi variabel bebas lain konstan.

A. Uji t Statistik

Berdasarkan perhitungan $t$-statistic yang diperoleh adalah $4,144>t$ tabel sebesar 2,977. Dengan nilai signifikan sebesar $0,000<\alpha$ sebesar 0,05 sehingga Ho ditolak. Jadi terdapat pengaruh dana zakat terhadap pertumbuhan ekonomi di Indonesia periode 2007-2018.

Tabel 5 Hasil Uji t Statistik

Coefficients ${ }^{a}$

\begin{tabular}{|c|c|c|c|c|c|}
\hline \multirow[b]{2}{*}{ Model } & \multicolumn{2}{|c|}{ Unstandardized Coefficients } & \multirow{2}{*}{$\begin{array}{l}\text { Standardized } \\
\text { Coefficients } \\
\text { Beta } \\
\end{array}$} & \multirow[b]{2}{*}{$\mathrm{T}$} & \multirow[b]{2}{*}{ Sig. } \\
\hline & $\mathrm{B}$ & Std. Error & & & \\
\hline 1 (Constant) & $\begin{array}{l}171926417812,54 \\
3\end{array}$ & 39344629374,959 & & 4,370 &, 000 \\
\hline $\begin{array}{l}\text { DANA } \\
\text { ZAKAT }\end{array}$ & 5,241 & 1,265 & ,591 & 4,144 & ,000 \\
\hline
\end{tabular}

Dependent Variable: PDB

Sumber : Data diolah, 2019

B. Uji F Statistik

Berdasarkan perhitungan $f$-statistic yang diperoleh adalah sebesar 17,173 >f table sebesar 4,45 dengan nilai p-value sebesar 0,000 < $\alpha$ sebesar 0,05 maka Ho ditolak. Jadi, terdapat pengaruh dana zakat terhadap pertumbuhan ekonomi di Indonesia periode 2007-2018.

Tabel 6 Hasil Uji f Statistik Analisis of Varian (ANOVA)

ANOVAa

\begin{tabular}{|ll|l|l|l|l|l|}
\hline Model & Sum of Squares & Df & Mean Square & F & Sig. \\
\hline 1 & Regression & 46550209731579 & 1 & 4655020973157970 & \multirow{2}{*}{17,173} &, $000^{\mathrm{b}}$ \\
& 7000000000,000 & & 00000000,000 & & \\
\multirow{3}{*}{ Residual } & 86742370420498 & 32 & 2710699075640589 & & \\
\multirow{3}{*}{ Total } & 8600000000,000 & & 3000000,000 & & \\
& 13329258015207 & 33 & & & \\
\hline
\end{tabular}

a. Dependent Variable: PDB

b. Predictors: (Constant), DANA ZAKAT

Sumber : Data diolah, 2019 
C. Koefisien Determinasi

Analisis koefisien determinasi digunakan untuk mengetahui seberapa jauh kemampuan persentase variabel dana zakat terhadap pertumbuhan ekonomi.

Tabel 7 Nilai Koefisien Determinasi

\begin{tabular}{|l|l|l|l|l|}
\hline \multicolumn{5}{|c|}{ Model Summary } \\
\hline Model & $\mathrm{R}$ & R Square & Adjusted R Square & $\begin{array}{l}\text { Std. Error of the } \\
\text { Estimate }\end{array}$ \\
\hline 1 &, $591^{\mathrm{a}}$ &, 349 &, 329 & 164642007872,857 \\
\hline
\end{tabular}

Sumber : Data diolah, 2019

Berdasarkan Tabel di atas dapat dilihat bahwa koefisien determinasi atau nilai Adjusted R-Squared dari hasil regresi di atas yaitu 32,9\%. Hal ini berarti menjelaskan variasi variabel terikat yaitu pertumbuhan ekonomi dapat dijelaskan oleh variabel bebas yaitu dana zakat sebesar $32,9 \%$. Sedangkan sisanya yaitu $67.1 \%$ dijelaskan oleh variabel lain yang tidak diteliti atau tidak dimasukkan dalam model penelitian ini.

Dari penelitian ini diperoleh nilai koefisien regresi sehingga terbentuk persamaan regresi yaitu : $\mathrm{Y}=\mathbf{1 7 1}, \mathbf{9 2 6}+\mathbf{0 , 5 9 1} \mathrm{X}+\mathrm{e}$

\section{Tabel 8 Hasil Koefisien Regresi}

Coefficientsa

\begin{tabular}{|c|c|c|c|c|c|}
\hline \multirow[b]{2}{*}{ Model } & \multicolumn{2}{|c|}{ Unstandardized Coefficients } & \multirow{2}{*}{$\begin{array}{l}\text { Standardized } \\
\text { Coefficients } \\
\text { Beta } \\
\end{array}$} & \multirow[b]{2}{*}{$\mathrm{T}$} & \multirow[b]{2}{*}{ Sig. } \\
\hline & $\mathrm{B}$ & Std. Error & & & \\
\hline 1 (Constant) & $\begin{array}{l}171926417812,54 \\
3\end{array}$ & 39344629374,959 & & 4,370 & 000 \\
\hline $\begin{array}{l}\text { DANA } \\
\text { ZAKAT }\end{array}$ & 5,241 & 1,265 & ,591 & 4,144 & 000 \\
\hline
\end{tabular}

Dependent Variable: PDB

Sumber : Data diolah, 2019

Dari formula model di atas maka dapat diartikan sebagai berikut:

1. Pada bagian ini dikemukakan nilai konstanta 171,926 dan mempunyai koefisien regresi sebesar 0,591 menunjukkan bila faktor dana zakat bernilai 0 (konstan), maka PDB sebesar =0,591. Ini menunjukkan angka positif yang artinya bahwa setiap peningkatan penerimaan dana zakat sebesar 1\%, maka akan terjadi perubahan PDB sebesar $=0,591$. Hal ini disebabkan karena zakat yang diberikan berpengaruh terhadap pendapatan masyarakat yang menerimanya sehingga dapat meningkatkan pendapatan skala nasional (PDB) yang pada akhirnya dapat meningkatkan pertumbuhan ekonomi Indonesia. 
2. Dari persamaan regresi diatas, diketahui bahwa koefisien korelasi $(R)=0,591$ atau $59,1 \%$ yang menunjukan bahwa derajat hubungan (korelasi) antara variabel bebas (dana zakat) dengan variabel terikat pertumbuhan ekonomi (PDB) memiliki hubungan (korelasi).

3. Dari tabel hasil juga dapat diketahui koefisien determinasi $\left(\mathrm{R}^{2}\right)$ hanya sebesar $=$ 0,329 atau $32,9 \%$. Ini berarti dalam variabel terikat (PDB) dapat dipengaruhi sebesar $32,9 \%$ oleh saluran dana zakat , dan sisanya sebesar $67,1 \%$ dipengaruhi oleh faktor lain yang tidak termasuk dalam penelitian ini. Dari hasil nilai determinasi $\left(\mathrm{R}^{2}\right)$ pengaruh dana zakat terhadap PDB relatif lemah, ini terjadi karena PDB harga konstan (ril) yang dianalisis dalam penelitian ini menunjukkan laju pertumbuhan ekonomi secara keseluruhan atau setiap sektor dari tahun ke tahun, namun angka yang digunakan pada penelitian ini dibatasi pada sektor pengeluaran konsumsi rumah tangga.

4. Mengacu pada hipotesis, maka pengujian dilakukan dengan uji-t. Berdasarkan perhitungan $t$-statistic yang diperoleh adalah 4,144 > t tabel sebesar 2,977. Dengan nilai signifikan sebesar $0,000<\alpha$ sebesar 0,05 sehingga Ho ditolak. Jadi terdapat pengaruh dana zakat terhadap pertumbuhan ekonomi di Indonesia periode 20072018. Sedangkan perhitungan $f$-statistic yang diperoleh adalah sebesar $17,173>\mathrm{f}$ table sebesar 4,45 dengan nilai p-value sebesar $0,000<\alpha$ sebesar 0,05 maka Ho ditolak. Jadi, terdapat pengaruh dana zakat terhadap pertumbuhan ekonomi di Indonesia periode 2007-2018. Ini berarti variabel dana zakat (X) berpengaruh terhadap pertumbuhan ekonomi dengan indikator PDB (Y).

\section{SIMPULAN}

Berdasarkan penelitian yang telah dilakukan maka dapat disimpulkan bahwa varibel dana zakat berpengaruh positif terhadap pertumbuhan ekonomi di Indonesia periode 2008-2018. Hal ini dikarenakan semakin tinggi penyaluran dana zakat menandakan semakin tinggi pula tingkat pertumbuhan ekonomi masyarakat di Indonesia. Selain disalurkan untuk tujuan konsumsi, dana zakat juga dapat juga disalurkan untuk efek jangka panjang yang lebih produktif, yang kemudian akan berdampak pada meningkatnya pendapatan golongan masyarakat mustahik (penerima zakat) dengan harapan di masa yang akan datang status mereka akan menjadi muzakki (pembayar zakat). Dengan semakin meratanya distribusi dana zakat maka akan dapat mendorong dan mengendalikan laju pertumbuhan ekonomi di Indonesia.

Hasil penelitian ini menunjukkan bahwa dana zakat $(\mathrm{X})$ berpengaruh positif terhadap pertumbuhan ekonomi indikator PDB di Indonesia periode 2007-2018. Hasil analisis dikemukakan nilai konstanta 171,926 dan mempunyai koefisien regresi sebesar 0,591 menunjukkan bila faktor dana zakat bernilai 0 (konstan), maka PDB sebesar =0,591. Ini menunjukkan angka positif yang artinya bahwa setiap peningkatan penerimaan dana zakat sebesar 1\%, maka akan terjadi perubahan PDB sebesar $=0,591$. Hal ini disebabkan karena zakat yang diberikan berpengaruh terhadap pendapatan masyarakat yang menerimanya sehingga dapat meningkatkan pendapatan skala nasional (PDB) yang pada akhirnya dapat meningkatkan pertumbuhan ekonomi Indonesia. Diketahui juga bahwa koefisien korelasi $(R)=0,591$ atau $59,1 \%$ yang menunjukan bahwa derajat hubungan 
(korelasi) antara variabel bebas (dana zakat) dengan variabel terikat pertumbuhan ekonomi (PDB) memiliki hubungan (korelasi). Koefisien determinasi ( ${ }^{2}$ ) diketahui sebesar $=0,329$ atau 32,9\%, artinya variabel terikat (PDB) dapat dipengaruhi sebesar 32,9\% oleh dana zakat, dan sisanya sebesar $67,1 \%$ dipengaruhi oleh faktor lain yang tidak termasuk dalam penelitian ini. Dari hasil nilai determinasi $\left(\mathrm{R}^{2}\right)$ pengaruh dana zakat terhadap PDB relatif lemah, ini terjadi karena PDB harga konstan (riil) yang dianalisis dalam penelitian ini menunjukkan laju pertumbuhan ekonomi secara keseluruhan atau setiap sektor dari tahun ke tahun, namun angka yang digunakan pada penelitian ini dibatasi pada sektor pengeluaran konsumsi rumah tangga.

Hasil uji-t berdasarkan perhitungan $t$-statistic yang diperoleh adalah $4,144>$ t tabel sebesar 2,977 dengan nilai signifikan sebesar 0,000 $<\alpha$ sebesar 0,05 sehingga Ho ditolak. Sedangkan perhitungan $f$-statistic yang diperoleh adalah sebesar 17,173 $>$ f table sebesar 4,45 dengan nilai p-value sebesar 0,000 < $\alpha$ sebesar 0,05 maka Ho ditolak. Maka dapat disimpulkan bahwa terdapat pengaruh dana zakat $(\mathrm{X})$ terhadap pertumbuhan ekonomi indikator PDB (Y) di Indonesia periode 2007-2018.

Dari simpulan tersebut, dapat dikemukakan beberapa saran antara lain:

A. Penulis memberikan saran kepada BAZNAS agar berupaya terus meningkatkan besaran dana zakat yang dihimpun sehingga dana zakat yang disalurkan untuk masingmasing mustahik dapat ditingkatkan pada program zakat konsumtif dan zakat produktif sehingga mampu meningkatkan pendapatan masyarakat mustahik sehingga mustahik akan mampu meningkatkan konsumsi rumah tangganya. Program zakat produktif yang disalurkan juga lebih efektif sehingga memberikan manfaat yang lebih besar bagi mustahik secara khusus dan pada perekonomian Indonesia secara umum.

B. Penulis merekomendasikan kepada Pemerintah agar lebih arif dalam menentukan kebijakan, terutama yang terkait langsung dengan masyarakat, dan melihat implikasi dari kebijakan tersebut dengan lebih bijaksana, seperti adanya Rancangan UndangUndang Pengelolaan Zakat dengan memasukkan aturan-aturan program yang sesuai dengan program pembangunan kesejahteraan berkelanjutan yang merupakan program pembangunan ekonomi dunia termasuk di Indonesia.

C. Diharapkan hasil penelitian ini dapat menjadi acuan bagi peneliti selanjutnya untuk mengembangkan penelitian dalam bidang ini dengan mempertimbangkan variabelvariabel lain yang belum dibahas dalam penelitian ini.

\section{DAFTAR PUSTAKA}

Hafidhuddin, Didin. 2002. Zakat dalam Perekonomian Modern. Gema Insani Press. Jakarta. Kahf, Monzer. 1955. Ekonomi Islam: Telaah Anlitik Terhadap Fungsi Sistem Ekonomi Islam. Yogyakarta: Pustaka Pelajar.

Naf'an. 2014. Ekonomi Makro Tinjauan Ekonomi Syari'ah.Yogyakarta: Graha Ilmu. Qadir, A. 1998. Zakat dalam DimensiMahdah dan Sosial.Jakarta: RajaGrafindo Persada. Qardhawi, Yusuf. 1991. Fiqih Zakat. Gema Insani Press. Jakarta. Qardhawi, Yusuf. 2005. Spektrum Zakat. Daar El-Syoruk.

Raharja \& Manurung. 2004. Teori Ekonomi Mikro: Suatu Pengantar. Jakarta:Lembaga Penerbit Fakultas Ekonomi Universitas Indonesia.

Riduwan, dan Sunarto. 2007. Pengantar Statistika Untuk Penelitian : Pendidikan, Sosial, Komunikasi, Ekonomi dan Bisnis. Bandung : Alfabeta. 
Ryandono, M.N. 2008. Ekonomi ZISWAQ (zakat,infak,shodaqoh dan wakaf).Surabaya: IFDI dan Cenforis.

Sabiq, Sayyid. 1968. Fiqh Sunnah. Kuwait: Daar El-Bayan.

Saefuddin, Ahmad Muflih. 1986. Pengelolaan Zakat Ditinjau Dari Aspek Ekonomi. Bontang: Badan Dakwah Islamiyyah, LNG.

Anggraini, Rachmasari, dkk. 2018. Pengaruh Penyaluran Dana ZIS dan Tingkat Inflasi Terhadap Pertumbuhan Ekonomi Indonesia Periode 2011-2015. Jurnal Ekonomi Syariah Falah Vol. 3 No. 2 Tahun Agustus 2018.

Damanhur, Nurainiah. 2016. Analisis Pengaruh Bantuan Zakat Terhadap Tingkat Kesejahteraan Masyarakat Kabupaten Aceh Utara. Jurnal Visioner dan Strategis Vol. 5 No. 2 September 2016.

Gunawan, H., \& Hadi, S. (2019). PENGARUH NISBAH BAGI HASIL DEPOSITO MUDHARABAH TERHADAP MINAT NASABAH BERINVESTASI PADA BANK SYARIAH MANDIRI CABANG TAJUR BOGOR PENGAMATAN 2017. Al-Mubin; Islamic Scientific Journal, 2(1), 37-50.

Murniati, Rina. 2014. Peran Zakat Dalam Pembangunan Manusia (Kasus Program Pendayagunaan Zakat BAZ Kota Bogor). Skripsi pada Departemen Ilmu Ekonomi FakultasEkonomi dan Manajemen Institut Pertanian Bogor

Muttaqin, M. Zainal. 1997. Kewajiban Menjadi Muzakki. Makalah pada seminar Zakat Antara Cita dan Fakta, Bogor.

Nurlita, dkk. Pengaruh Zakat Terhadap Konsumsi Rumah Tangga Mustahiq. Jurnal Ekonomi dan Bisnis Islam Vol. 3 No. 2 Juli-Desember 2017.

Nurzaman, Mohamad Soleh.2010. Zakat and Human Development: An Empirical Analysis on Poverty Alleviation in Jakarta, Indonesia. Penelitian ini didukung oleh Skema Dukungan Penelitian dari Direktorat Penelitian dan Pengabdian Masyarakat Universitas Indonesia, memberikan no. 2607 / H2.R12 / PPM.00.01 Sumber Jiwa Manulife / 2010. Dan dipresentasikan dalam Konferensi Internasional Kedelapan Tentang Ekonomi dan Pembiayaan Islam di Qatar.

Puspita, Devialina. 2008. Pengaruh Pendayagunaan Zakat Terhadap Keberdayaan dan Pengentasan Kemiskinan Rumah Tangga (Kasus: Program Urban Masyarakat Mandiri, Kelurahan Bidaracina, Kecamatan Jatinegara, Jakarta Timur). Skripsi pada Pogram Studi Komunikasi dan Pengembangan Masyarakat Fakultas Pertanian Institut Pertanian Bogor.

Roisiyatin. 2012. Analisis Inflasi Terhadap Jumlah Dana Pihak Ketiga Perbankan Syariah di Indonesia Tahun 2009-2011. Skripsi pada Program Studi Ekonomi Islam Fakultas Ekonomi dan Bisnis Syariah Universitas Djuanda Bogor.

Roisiyatin. 2016. Analisis Kesejahteraan Mustahiq dan Non Mustahiq Perspektif Maqaashidus Syariah : Studi Kasus Program Pemberdayaan Petani Sehat Dompet Dhuafa dan Program Nasional Pemberdayaan Masyarakat. Tesis pada Program Pascasarjana Kajian Stratejik Global Kekhususan Ekonomi dan Keuangan Syariah Universitas Indonesia.

Romdhoni, Abdul Haris. 2017. Zakat Dalam Mendorong Petumbuhan Ekonomi dan Pengentasan Kemiskinan. Jurnal Ilmiah Ekonomi Islam Vol. 3 No. 1 Maret 2017.

www.baznas.go.id

www.bps.go.id 